\title{
Pain Assessment in Patients Who Receive Hemodialysis Treatment
}

\section{Hemodiyaliz Tedavisi Gören Hastalarda Ağrı Değerlendirmesi}

\author{
SŞeyda Can', @Arzu Arda² \\ 'Yalova University Faculty of Health Sciences, Medical Nursing Department, Yalova, Turkey \\ 2Bursa Yüksek Ihtisas Education and Research Hospital, Dialysis Unit, Bursa, Turkey
}

\begin{abstract}
Aim: Pain is an important health issue that is common among patients who receive hemodialysis treatment and greatly affects the patients' quality of life. This study aims to assess the qualitative pain characteristics of patients who receive hemodialysis treatment using the McGill Pain Questionnaire.
\end{abstract}

Material and Method: This descriptive and cross-sectional study included 87 patients who received HD treatment. Data were collected using an information form and the McGill Pain Questionnaire in the HD clinic of a training and research hospital in Turkey between 01.04.2019 and 31.09.2019.

Results: The study is found that the mean current pain scores of the HD patients were moderate $(2.13 \pm 0.56)$. The study is determined that the patients experienced pain most often in the lower extremity (36.8\%) and head region (29.9\%) and least in the upper extremity (11.5\%). The hemodialysis procedure $(44.8 \%)$, not following the diet $(23 \%)$, fatigue $(16.1 \%)$ and stress $(16.1 \%)$ were found to intensify the pain. The study is found that analgesics $(36.8 \%)$, resting $(31 \%)$, complementary approaches $(17.2 \%)$ and other practices $(14.9 \%)$ relieved pain when patients were in pain. The study is also found that the patients often used the words tiring $(n=47)$, sickening $(n=42)$, fearful $(n=41)$, and wretched $(n=38)$ to define the pain they felt.

Conclusion: Measuring pain are greatly important to increase the quality of life. The results obtained indicate that assessment of the pain individualistically will be a guide to provide a holistic approach in HD patients.

Keywords: Pain, pain measurement, hemodialysis, McGill Pain Questionnaire

\section{Öz}

Amaç: Hemodiyaliz (HD) tedavisi gören hastalarda ağrı sık görülen ve büyük ölçüde yaşam kalitesini etkileyen önemli bir sağlık problemidir. Bu araştırma, McGill Ağrı Anketi ile hemodiyaliz tedavisi gören hastaların kalitatif ağrı özelliklerini değerlendirmeyi amaçlamaktadır.

Gereç ve Yöntem: Araştırma, hemodiyaliz tedavisi gören 87 hasta ile gerçekleştirilen tanımlayıcı ve kesitsel bir çalışmadır. Veriler bilgi formu ve McGill Ağı Anketi aracılığıyla 01.04.2019-31.09.2019 tarihleri arasında Türkiye'de bir eğitim araştırma hastanesinin hemodiyaliz kliniğinde toplandı.

Bulgular: Çalışmada HD hastalarının var olan ağrı şiddeti puan ortalamalarının orta düzeyde $(2,13 \pm 0,56)$ olduğu belirlendi. Katılımcıların en sık alt ekstremite $(\% 36,8)$, ve baş bölgesinde $(\% 29,9)$ en az üst ekstremitede $(\% 11,5)$ ağı deneyimlediği saptandı. Hemodiyaliz işlemi $(\% 44,8)$, diyete dikkat etmemek $(\% 23)$, yorgunluk $(\% 16,1)$ ve stresin $(\% 16,1)$ ağrıyı artırdığı belirlendi. Hastaların ağrısı olduğunda ise sırası ile analjeziklerin (\%36,8), istirahat etmenin (\%31), tamamlayıc yaklaşımların $(\% 17,2)$ ve diğer uygulamaların $(\% 14,9)$ ağrıyı azalttığı belirlendi. Hastaların hissettikleri ağrıları tanımlarken sıklıkla yorucu $(n=47)$, tiksindirici $(n=42)$, korku veren $(n=41)$ ve sefil eden $(n=38)$ ifadelerini kullandığı görüldü.

Sonuç: Yaşam kalitesinin artırılmasında ağrıyı değerlendirmek son derece önemlidir. Elde edilen sonuçların hemodiyaliz hastalarında, ağrıyı bireye özgü değerlendirerek bütüncül bir yaklaşımın sunulmasında yol gösterici olacağı düşünülmektedir.

Anahtar Kelimeler: Ağrı, ağrı ölçümü, hemodiyaliz, McGill Pain Questionnaire 


\section{INTRODUCTION}

Kidney diseases are a global health issue that affects more than 750 million people worldwide. ${ }^{[1,2]}$ While the symptoms and findings induced by kidney failure are brought under control with hemodialysis treatment, the treatment process and maintaining a life depending on the hemodialysis machine may cause different problems. ${ }^{[3]}$ Patients who receive hemodialysis treatment struggle against significant health problems such as sleep disorder, depression, fluctuations in vital signs and pain. ${ }^{[4]}$ Acute and chronic pain is an important health problem common among especially the population of patients who receive hemodialysis treatment that significantly affects their quality of life. ${ }^{[5]}$ Pain negatively affects the coping process, functional capacity and direct quality of life. ${ }^{[6]}$

Pain is an experience that affects the individual with all dimensions and it is quite common among hemodialysis patients. ${ }^{[7]}$ The International Association for the Study of Pain (IASP) defines pain as an unpleasant sensory and emotional experience associated with real or possible tissue damage. ${ }^{[8]}$ Personal experiences and their responses change in every person; thus, pain is a subjective concept. However, reasons such as the patient's fear of disrupting the healthcare staff, belief that nothing will reduce the pain, fear of disbelief, and lack of a common language to discuss pain cause patients to be reluctant to communicate about their pain levels. [9] Additionally, since the priority is generally given to the treatment of the current disease in hemodialysis patients, the number of approaches related to the existence, etiology and management of pain is limited. ${ }^{[10]}$

The increasing incidence frequency, morbidity, mortality rates of kidney diseases and costly treatments make kidney diseases an important public health problem. ${ }^{[2]}$ Considering that the pain incidence of patients who receive hemodialysis treatment due to kidney failure are high, it is also an important necessity to examine the existence, intensity, frequency, duration of pain and increasing/decreasing factors. The pain must be defined accurately to provide individualistic and holistic care regarding the concept of pain that is perceived differently by everyone and affected by personal factors. Pain assessment is important for healthcare personnel to provide effective pain management with accurate knowledge, behavior, attitude, assessment and clinical decision-making skill to increase the patients' quality of life. ${ }^{[11,12]}$ Therefore, the results obtained in this study are considered to be guiding in the clinical area.

\section{Research Question}

What are the pain levels of hemodialysis patients?

\section{MATERIALS AND METHOD}

\section{Design and Setting}

This descriptive and cross-sectional study was carried out to determine the pain conditions of patients who received hemodialysis treatment.

\section{Sample}

The population of the study is included the patients who applied to the hemodialysis clinic of a training and research hospital in Turkey for treatment between 01.04.2019 and 31.09.2019. The aim was to reach all registered chronic regular hemodialysis patients in the service between these dates. A total of 230 individuals applied to the hemodialysis service of the hospital where the study was conducted as hemodialysis patients between the specified dates. While approximately 98 of these patients were registered chronic regular hemodialysis patients in the service, the rest were acute and temporary patients. The sample of the study included 87 patients who met the inclusion criteria and who agreed to participate in the study voluntarily.

\section{Sample Selection Criteria of the Study;}

- Being 18 or older.

- Receiving hemodialysis treatment in the relevant hospital.

- Receiving hemodialysis treatment for at least one year.

- Having pain.

- Knowing Turkish.

\section{Data Tools}

The data were collected using an information form and the McGill Pain Questionnaire.

\section{Information Form}

The structured information form used to collect data was formed by the researchers in line with the knowledge of literature. ${ }^{[6,10,15]}$ This form questioned the descriptive characteristics of the patients and included 13 questions related to demographic characteristics (age, sex), socioeconomic characteristics (education level, employment status) and disease history (the date of the first dialysis, frequency of dialysis, comorbid disease).

\section{The McGill Pain Questionnaire (MPQ)}

The McGill Pain Questionnaire (MPQ) was developed by Melzack in 1975. ${ }^{[13]}$ The MPQ is the most commonly used survey for the multidimensional assessment of pain. It provides information about the sensory characteristics, intensity and effect of pain. The Turkish validity and reliability of it was conducted by Kuguoglu, Aslan and Olgun (2003). ${ }^{[14]}$ The coefficient reliability measured with the Cronbach's alpha was found as 0.98. The item reliability coefficients of the form parts were between 0.52 and 0.72 in the second part, between 0.50 and 0.70 in the third part and between 0.50 and 0.58 in the fourth part. The scale consists of four parts. The first part of the form includes information about the patient's age, medical diagnosis-problem, type and dosage of analgesics if used, as well as descriptive information about the patient's level of perception. In summary, the location of the pain, its relationship with time, its intensity, the feeling it creates in the patient and the livable pain for the patient are determined in the measurement made using the McGill Pain Questionnaire. Evaluation is made on an assessment scale consisting of words used to describe the pain intensity. 


\section{Data Collection}

Data were collected using the face-to-face interview technique. The data were collected by the researchers in the hemodialysis service or in the waiting area within 15-20 minutes without hindering the patient's treatment protocol and the functioning of the service. It is seen in the literature that most patients who receive dialysis treatment and have chronic kidney problem experience pain. ${ }^{[6]}$ It is also seen that the location and intensity of pain experienced before, during and after hemodialysis change. The patients' data were collected during the dialysis process in this study.

\section{Ethical Considerations}

Approval from the ethics committee (2011-KAEK-25 2019/0202) and the hospital was obtained before the study was conducted. All persons included in the study signed the Informed Consent Form. The design and conduct of the study was in accordance with the general principles outlined in the Declaration of Helsinki and adhered to principles of Good Clinical Practice.

\section{Statistical Analysis}

Data analysis was performed through SPSS for Windows (Statistical Package for the Social Science for Windows, Version 24.0). The arithmetic mean, standard deviation, minimum and maximum values were adopted in the assessment of the numeric variables whereas in the assessment of the categorical variables, frequency and percentage were employed.

\section{RESULTS}

The demographic characteristics of the patients are presented in Table 1. The mean age of the patients included in the sample was $51.63 \pm 18.84$. Of the participants, $52.9 \%$ were male, $81.6 \%$ were married, $62.1 \%$ were primary school graduates, $93.1 \%$ were unemployed and $52.9 \%$ defined their economic state as good. Of the patients, $70.1 \%$ had at least one comorbid disease besides kidney failure, $58.6 \%$ had been receiving dialysis treatment for $1-5$ years, and $80.4 \%$ received hemodialysis treatment three days a week. Considering the BMI values of the patients, most of them (57.5\%) had normal body weight. The number of patients who did not have any harmful substance abuse was determined to be $n=62(71.3 \%)$.

The mean level of perception of the patients was found to be moderate (3.49 \pm 1.07$)$. The patients' mean current pain intensity score was $2.13 \pm 0.56$ and the worst pain intensity was at the level of $3.28 \pm 0.98$ points. Considering the analgesics the patients prefer when in pain, it was found that most of them (86.2\%) used paracetamol. Also, the remaining 13.8\% used nonsteroidal analgesics. The most commonly reported region among aching body parts of the participants was lower extremity (36.8\% followed by head region (29.9\%). The least pain was detected in the upper extremity region (11.5\%). Of the participants, $67.8 \%$ described their pain as superficial and 54\% described the pain's relationship with time as brief, momentary and transient .The conditions that intensify and reduce the pain were examined in this study. The hemodialysis procedure (44.8\%), not following the diet $(23 \%)$, fatigue $(16.1 \%)$ and stress (16.1\%) were found to intensify the pain. The study found that analgesics (36.8\%), resting (31\%), complementary approaches (17.2\%) and other applications (14.9\%) relieved pain when patients were in pain (Table 2 ).

Table 1. Distribution of the patients' demographic characteristics

\begin{tabular}{|c|c|c|}
\hline Variables & Min-Max. & Mean $\pm S d$ \\
\hline Mean Age & $18-96$ & $51.63 \pm 18.84$ \\
\hline Weight & $30-122$ & $64.37 \pm 15.20$ \\
\hline \multirow[t]{2}{*}{ Height } & $140-183$ & $163.87 \pm 8.98$ \\
\hline & $\mathbf{n}$ & $\%$ \\
\hline \multicolumn{3}{|l|}{ Age Groups } \\
\hline $18-43$ & 31 & 35.6 \\
\hline $44-70$ & 42 & 48.3 \\
\hline $71-96$ & 14 & 16.1 \\
\hline \multicolumn{3}{|l|}{ Body Mass Index } \\
\hline *Lower than 18.5 kg/m² & 10 & 11.5 \\
\hline †Between $18.5-24.9 \mathrm{~kg} / \mathrm{m}^{2}$ & 50 & 57.5 \\
\hline キHigher than 25 kg/m² & 27 & 31 \\
\hline \multicolumn{3}{|l|}{ Gender } \\
\hline Female & 41 & 47.1 \\
\hline Male & 46 & 52.9 \\
\hline \multicolumn{3}{|l|}{ Marital status } \\
\hline Married & 71 & 81.6 \\
\hline Single & 16 & 18.4 \\
\hline \multicolumn{3}{|l|}{ Educational Level } \\
\hline Literate & 19 & 21.8 \\
\hline Primary school & 54 & 62.1 \\
\hline High school & 11 & 12.6 \\
\hline University & 3 & 3.4 \\
\hline \multicolumn{3}{|l|}{ Employment Status } \\
\hline Employed & 6 & 6.9 \\
\hline Unemployed & 81 & 93.1 \\
\hline \multicolumn{3}{|l|}{ Economic Status } \\
\hline Good & 46 & 52.9 \\
\hline Moderate & 37 & 42.5 \\
\hline Bad & 4 & 4.6 \\
\hline \multicolumn{3}{|l|}{ Duration of Hemodialysis (year) } \\
\hline Between $1-5$ years & 51 & 58.6 \\
\hline Between 6-10 years & 26 & 29.9 \\
\hline More than 11 years & 10 & 11.5 \\
\hline \multicolumn{3}{|c|}{ Frequency of Undergoing Dialysis (week) } \\
\hline 2 & 17 & 19.5 \\
\hline 3 & 70 & 80.5 \\
\hline \multicolumn{3}{|l|}{ Using Harmful Substances } \\
\hline Yes & 25 & 28.7 \\
\hline No & 62 & 71.3 \\
\hline \multicolumn{3}{|l|}{ Comorbid Disease } \\
\hline Yes & 61 & 70.1 \\
\hline No & 26 & 29.9 \\
\hline
\end{tabular}

*Underweight + Normal $\neq$ Overweight 


\begin{tabular}{|c|c|c|}
\hline Variables & Min-Max. & Mean $\pm S d$ \\
\hline Level of Perception & $1-5$ & $3.49 \pm 1.07$ \\
\hline $\begin{array}{l}\text { Pain intensity } \\
\text { Current Pain Score (0-5) } \\
\text { Worst Pain Score }(0-5)\end{array}$ & $\begin{array}{c}1-4.33 \\
1-5\end{array}$ & $\begin{array}{l}2.13 \pm 0.56 \\
3.28 \pm 0.98\end{array}$ \\
\hline & $\mathbf{n}$ & $\%$ \\
\hline Analgesic Used & & \\
\hline $\begin{array}{l}\text { Paracetamol } \\
\text { Nonsteroidal }\end{array}$ & $\begin{array}{l}75 \\
12\end{array}$ & $\begin{array}{l}86.2 \\
13.8\end{array}$ \\
\hline $\begin{array}{l}\text { Pain Location } \\
\text { Head Region } \\
\text { Abdominal Region } \\
\text { Lower extremity } \\
\text { Upper extremity }\end{array}$ & $\begin{array}{l}26 \\
19 \\
32 \\
10\end{array}$ & $\begin{array}{l}29.9 \\
21.8 \\
36.8 \\
11.5\end{array}$ \\
\hline $\begin{array}{l}\text { Deep/Superficial } \\
\text { Deep } \\
\text { Superficial } \\
\text { Deep and Superficial }\end{array}$ & $\begin{array}{l}22 \\
59 \\
56\end{array}$ & $\begin{array}{c}25.3 \\
67.8 \\
6.9\end{array}$ \\
\hline $\begin{array}{l}\text { The Relationship of Pain with Time } \\
\text { Continuous, steady, constant } \\
\text { Rhythmic, periodic, intermittent } \\
\text { Brief, momentary, transient }\end{array}$ & $\begin{array}{l}18 \\
22 \\
47\end{array}$ & $\begin{array}{l}20.7 \\
25.3 \\
54.0\end{array}$ \\
\hline $\begin{array}{l}\text { What relieves the pain } \\
\text { Analgesics } \\
\text { Resting } \\
\text { Complementary Approaches* } \\
\text { Other Applicationst }\end{array}$ & $\begin{array}{l}32 \\
27 \\
15 \\
13\end{array}$ & $\begin{array}{c}36.8 \\
31 \\
17.2 \\
14.9\end{array}$ \\
\hline $\begin{array}{l}\text { What intensifies the pain } \\
\text { Fatigue } \\
\text { Stress } \\
\text { Not following the diet } \\
\text { Dialysis }\end{array}$ & $\begin{array}{l}14 \\
14 \\
20 \\
39\end{array}$ & $\begin{array}{c}16.1 \\
16.1 \\
23 \\
44.8\end{array}$ \\
\hline
\end{tabular}

In Table 3, the word sets that describe pain in individuals who receive hemodialysis treatment in terms of sensory, affective, miscellaneous and evaluative classes. The patients used the following words most commonly to describe pain; "wretched" in the sensory class $(n=38)$, "tiring" in the affective class $(n=47)$, "numb" in the evaluative class $(n=14)$, and "fearful" in the miscellaneous class $(n=41)$.

\begin{tabular}{|c|c|c|}
\hline Descriptors* & Frequencies & $\%$ \\
\hline $\begin{array}{l}\text { Sensory } \\
\text { Wretched } \\
\text { Flickering } \\
\text { Spreading } \\
\text { Tugging } \\
\text { Hot }\end{array}$ & $\begin{array}{l}38 \\
36 \\
36 \\
34 \\
33\end{array}$ & $\begin{array}{l}4.4 \\
4.1 \\
4.1 \\
3.9 \\
3.8\end{array}$ \\
\hline $\begin{array}{l}\text { Affective } \\
\text { Tiring } \\
\text { Sickening } \\
\text { Tight } \\
\text { Grueling } \\
\text { Nauseating }\end{array}$ & $\begin{array}{l}47 \\
42 \\
25 \\
19 \\
19\end{array}$ & $\begin{array}{l}5.4 \\
4.8 \\
2.9 \\
2.2 \\
2.2\end{array}$ \\
\hline $\begin{array}{l}\text { Evaluative } \\
\text { Numb } \\
\text { Squeezing } \\
\text { Tight } \\
\text { Drawing } \\
\text { Tearing }\end{array}$ & $\begin{array}{c}14 \\
13 \\
12 \\
8 \\
6\end{array}$ & $\begin{array}{l}1.6 \\
1.5 \\
1.4 \\
0.9 \\
0.7\end{array}$ \\
\hline $\begin{array}{l}\text { Miscellaneous } \\
\text { Fearful } \\
\text { Cool } \\
\text { Cutting } \\
\text { Jumping } \\
\text { Flashing }\end{array}$ & $\begin{array}{l}41 \\
34 \\
31 \\
23 \\
21\end{array}$ & $\begin{array}{l}4.9 \\
3.9 \\
3.6 \\
2.6 \\
2.4\end{array}$ \\
\hline
\end{tabular}

\section{DISCUSSION}

It is necessary to determine the perception levels of individuals who are in pain for the accurate description and effective management of pain. Therefore, the study was determined that the patients' perception level. The patients' perception levels were examined with a Likert-evaluation between 1-5 in the McGill pain questionnaire. Individuals' perception levels are important in interpreting their environment and themselves by understanding them. The study is found that the patients' perception levels were moderate. Cognition and perception are of great importance for the individual to interact with their environment purposefully and successfully. Cognition enables the individual to process, store and manage the information while perception enables the integration of sensations with meaningful information. On the other hand, cognitive and perceptive impairment affects self-care and conscious decisionmaking capacity. ${ }^{[15]}$ Some diseases (paralysis), treatments (chemotherapy) and physiological changes (increasing age) increase the risk of cognitive decline. ${ }^{[16]}$ Especially the negative effects of pain experienced on sleep, focus, memory, physical and social activities are known. ${ }^{[6]}$ The fact that the participants' perception levels were moderate in this study makes it important to describe and express pain perceptions accurately.

The study is determined that the patients' perception level. The study is determined that the patients' mean current pain intensity score was 2.13 out of 5 and the worst pain intensity was at the level of 3.28 points. The study is found that the worst pain intensity was higher than the current pain intensity and a bit over moderate intensity. Kafkia et al. (2014) found that the patients scored the pain they experienced as 6 out of 10. ${ }^{[17]}$ Özyiğit et al. (2016) found that the lowest pain score of the individuals who received hemodialysis treatment was 1.35 (mild) and the most intense pain score was 4.25 points out of $5 .{ }^{[6]}$ In the same study, $51.4 \%$ of the patients stated that the pain they experienced was mildly intense. Ghonemy et al. (2016) found that $52 \%$ of the patients were in pain and $48 \%$ of those in pain stated that their pain intensity was high. In the comparison with the literature, the patients in this study experienced a slightly lower level of pain. ${ }^{[18]}$ This result might be related to the population (sex) with whom the study was conducted and the time of pain inquiry (during/after dialysis). Considering the types of analgesics the patients prefer when in pain, it was found that most of them used paracetamol while some used nonsteroidal analgesics. Similarly, Caravaco et al. (2016) found that majority of patients with chronic kidney disease used paracetamol or metamizole as analgesic and more than $20 \%$ of the patients with muscle pain meticulously took nonsteroidal anti-inflammatory drugs. ${ }^{[19]}$ Sadigova et al. (2020) found that only $36.4 \%$ of patients who received hemodialysis treatment used analgesics, and the reasons why they did not want to use analgesics even though they were in pain might be the patients' concerns about the side effects of the drug, drug overload and addiction risks. ${ }^{[12]}$ Özer et al. (2020) determined that the hemodialysis patients' psychological pain beliefs were higher, pain coping methods were insufficient, 
and that as the patients' belief that psychological reasons are effective in the development of pain increases, the methods of seeking medical remedies decrease. ${ }^{[20]}$ The present study found that all participants used analgesics, although not regularly, and they often preferred paracetamol group. This indicates that it is necessary to examine the factors (doctor's suggestion, prejudices, friend's recommendation, experience, etc.) that affect the analgesics preference of hemodialysis patients in detail.

The most commonly reported region among the body parts where the participants perceived pain was lower extremity and head regions. The least pain was detected in the upper extremity region. In the study by Yeşil et al. (2015) conducted with hemodialysis patients, it was found that the patients' pain complaints were mostly headache (31 patients, $58.5 \%$ ), lower extremity pain (21 patients, 39.6\%) and pain induced by cramp-like contractions (28 patients, 52.8\%). ${ }^{[10]}$ Low back pain is common among hemodialysis patients. Old age, increased body mass index and smoking are the main risk factors for low back pain. The existence of low back pain is also associated with bad quality of life related to health. [21,22] In the study by Özyiğit et al. (2016), it was found that individuals who receive hemodialysis treatment often experience pain in the head, abdomen, and musculoskeletal areas. ${ }^{[6]}$ It was thought that the high rate of pain in the head area may be due to hemodialysis procedure. Caravaca et al. (2016) found that 38\% of 1169 patients with chronic kidney disease had chronic musculoskeletal pain..$^{[19]}$ In a systematic review addressing the hemodialysis patients, most of the patients stated to experience pain as arteriovenous access (AVF), headache and musculoskeletal pain. ${ }^{[5]}$ Sadigova et al. (2020) found that the most common pain region in patients who received hemodialysis treatment was lower extremity and that the patients with upper extremity pain had high AVF usage rates. 12 of the patients, 55.4\% experienced pain during the day and $16.3 \%$ stated that they experience headache the most. ${ }^{[20]}$ Ghonemy et al. (2016) stated that patients experience muscle, skeleton and headache the most. ${ }^{[18]}$ In a study which examined the problems experienced by patients after hemodialysis, it was found that $63.4 \%$ of the patients had headache. ${ }^{[23]}$ The results of the present study are similar to the studies in the literature, and the pain experienced appears to be in the musculoskeletal system ${ }^{[18,19]}$ and often in the lower extremities. ${ }^{[12]}$

While most of the hemodialysis patients in this study described their pain as superficial, they stated the relationship of their pain with time as brief, momentary and transient. Unlike the results obtained from this study, the patients in the study by Yeşil et al. (2015) described the nature of their pain as blunt, tingling and constant. ${ }^{[10]}$ Most patients reported that the pain started slowly. Similarly, it was found in another study that the pain experienced by patients was mild and deep. ${ }^{[6]}$ Different results obtained from the study might be related to the sample (age, sex) on which the study was conducted and the time of pain inquiry.
The study is examined the factors that intensify the pain in hemodialysis patients. Hemodialysis process, not following the diet, fatigue and stress were found to intensify the pain, respectively. Similar to the results obtained in this study, in the study by Sadigova et al. (2020) conducted with patients who receive hemodialysis treatment, the patients who experience pain had a longer duration of dialysis than patients who do not experience pain. ${ }^{[12]}$ It is stated that hemodialysis process and stress increase the pain. ${ }^{[6]}$ Following the therapeutic diet determines treatment success, quality of life and survival rates in hemodialysis patients. However, noncompliance with the diet continues to be serious health problem. ${ }^{[24]}$ The results obtained from the study are similar to the literature.

The study is found that analgesics, resting, complementary approaches (massage, hot/cold applications, etc.) and other applications (walking, eating certain food, etc.) reduce pain in hemodialysis patients, respectively. Özyiğit et al. (2016) found that more than half of the hemodialysis patients used pharmacological treatments for pain relief and almost half of them used nonpharmacological methods such as massage, hot application, position changing. ${ }^{[6]}$ Reiki, one of the complementary approaches, is known to provide symptom relief for individuals who receive hemodialysis. ${ }^{[25]}$ The study is found that the patients did not primarily use complementary approaches, preferred analgesics and expected pain relief with rest. Although pain is one of the most common symptoms in patients with kidney problem, it is not recognized enough, its severity is underestimated and its treatment is inadequate. ${ }^{[26]}$ The way followed in pain management in the study supports this information.

The patients who received hemodialysis treatment used the words "wretched" in the sensory class, "tiring" in the affective class, "numb" in the evaluative class, "fearful" in the miscellaneous group the most in this study. In a study which questioned the nature of pain in hemodialysis patients, the pain was described as blunt and tingling. ${ }^{[10]}$ In the study by Ruela et al. (2018), the following pain descriptions were reported by patients who received chemotherapy; burning and sore as the sensorial descriptor, tiring and sickening as the emotional descriptor, troublesome and annoying as the evaluative descriptor, radiating and nauseating as the miscellaneous group descriptors. ${ }^{[27]}$ Barbosa et al. (2016) found that the following words were preferred by onco-hematological patients the most; jumping, tugging and throbbing in the sensory category, exhausting, punishing and cruel in the affective category, troublesome, intense and miserable in the evaluative category, and penetrating, tight and dreadful in the miscellaneous category. ${ }^{[28]}$ Pain is a subjective and highly personal experience. The subjective nature of pain requires us to rely on individuals' self-expression and to some extent their behavior in pain assessment. ${ }^{[29]}$ Determining the perception differences in pain experience will affect the approaches in pain management. Therefore, the pain descriptions obtained in this study are important to reflect the pain perceptions of hemodialysis patients. 


\section{CONCLUSION}

In conclusion, the fact that pain is a personal sensation makes it necessary for us to consider that the one who can describe the pain in the most reliable way is the patient itself. This study determined and revealed the type, frequency, localization, intensity and characteristics of pain experienced by patients who receive dialysis treatment. Healthcare personnel should assess pain in hemodialysis patients using suitable tools to strengthen their communication with the patients. The results to be obtained are considered to be a resource for future studies and practices of healthcare personnel

\section{ETHICAL DECLARATIONS}

Ethics Committee Approval: Approval from the ethics committee (2011-KAEK-25 2019/02-02) and the hospital was obtained before the study was conducted.

Informed Consent: All patients signed the free and informed consent form.

Referee Evaluation Process: Externally peer-reviewed.

Conflict of Interest Statement: The author(s) declared no potential conflicts of interest with respect to the research, authorship, and/or publication of this article.

Financial Disclosure: The authors declared that this study has received no financial support.

Author Contributions: All of the authors declare that they have all participated in the design, execution, and analysis of the paper, and that they have approved the final version.

\section{REFERENCES}

1. Bikbov B, Perico N, Remuzzi G. Disparities in chronic kidney disease prevalence among males and females in 195 countries: Analysis of the global burden of disease 2016 study. Nephron 2018;139(4):313-8.

2. Crews DC, Bello AK, Saadi G. 2019 World Kidney Day Editorial - burden, access, and disparities in kidney disease. J Bras Nefrol 2019;41(1):1-9.

3. Şanlitürk D, Ovayolu N, Kes D. Common problems in hemodialysis patients and the problem solving recommendations. J Nephrol Nurs 2018;1(13):17-25.

4. Dąbrowska-Bender M, Dykowska G, Żuk W, Milewska M, Staniszewska A. The impact on quality of life of dialysis patients with renal insufficiency. Patient Prefer Adherence 2018;12:577-83.

5. Brkovic T, Burilovic E, Puljak L. Prevalence and severity of pain in adult end-stage renal disease patients on chronic intermittent hemodialysis: A systematic review. Patient Prefer Adherence 2016;22(10):1131-50.

6. Özyiğit S, Yıldırım Y, Karaman E. Pain in hemodialysis patients. Turk Neph Dial Transpl 2016;25(1):88-94.

7. İtişgen V, Kara B. Pain management in hemodialysis patients. J Nephrol Nurs 2016;2:1-8.

8. Hanoch Kumar K, Elavaras P. Definition of pain and classification of pain disorders. J Adv Clin Res Insights 2016;3:87-90.

9. Miller LE, Eldredge SA, Dalton ED."Pain is what the patient says it is":Nursepatient communication, information seeking, and pain management. Am J Hospice Palliat Med 2016;34(10):966-76.

10. Yeşil S, Karslı B, Kayacan N, Süleymanlar G, Ersoy F. Pain evaluation in patients with chronical renal failure undergoing hemodialysis. AGRI 2015;27(4):197-204.

11. Özveren H, Faydalı S, Gülnar E, Faydalı Dokuz H. Attitude and applications of nurses to evaluate pain. J Contemp Med 2018;8(1):60-6.
12. Sadigova E, Ozkurt S, Yalcin A. Pain assessment in hemodialysis patients. Cureus 2020;12(2):e6903.

13. Melzack R. The McGill Pain Questionnaire: major properties and scoring methods. Pain 1975;1:277-99.

14. Kuguoglu S, Aslan FE, Olgun N. The Turkish adaptation of the McGill Melzack pain questionnaire (MPQ). Pain 2003;15:47-51.

15. San A, Hiremagalur B, Muircroft W, Grealish L. Screening of cognitive impairment in the dialysis population: A scoping review. Dement Geriatr Cogn Disord 2017;44:182-95.

16. Tang EY, Amiesimaka O, Harrison SL, Green E, Price C, Robinson L, Siervo M, Stephan BC. Longitudinal Effect of Stroke on Cognition: A Systematic Review. J Am Heart Assoc 2018;7(2):e006443.

17. Kafkia T, Vehvilainen- Julkunen K, Sapountzi- Krepia D. Assessment and management of pain in hemodialysis patient: A pilot study. Prog Health Sci 2014;4(1):53-60.

18. Ghonemy TA, Allam HM, Elokely AM, Kadry YA, Omar HM. Chronic pain in hemodialysis patients: Role of bone mineral metabolism. Alexandria J Med 2016;2(4):337-42.

19. Caravaca F, Gonzales B, Bayo MA, Luna E. Dolor músculo-esquelético en pacientes con enfermedad renalcrónica. Nefrologia 2016;36:433-40.

20. Özer Z, Bahçecioğlu Turan G, Çelikbilek F. Relationship between pain beliefs and pain management in hemodialysis patients. J Nephrol Nurs 2020;15(3):226-34.

21. Bilgiç M, Duymaz T. An investigation of the effects of posture corrective exercise and stretch combination on flexibility pain and depression score in the late adolescence period. IGUSABDER 2018;4:318-29.

22. Kesikburun B, Ekşioğlu E, Akdağ I, Çakçı A. Low back pain in hemodialysis patients: Risk factors and its impact on health-related quality of life. Turk J Phys Med Rehab 2018;64(1):66-71

23. Akça N, Arslan D. Pain and coping methods of individuals under 65 years of age on hemodialysis treatment. Turk Neph Dial Transpl 2015;24(3):27882.

24. González Oquendo, L, Morales Asencio JM, Bonill de las Nieves C. Contributing factors for therapeutic diet adherence in patients receiving haemodialysis treatment: an integrative review. J Clin Nurs 2017;26:3893-905.

25. Zins S, Hooke MC, Gross CR. Reiki for pain during hemodialysis: A feasibility and instrument evaluation study. J Holistic Nurs 2019;37(2):148-62.

26. Holly M, Koncicki MU, Schell JO. Pain management in CKD: A guide for nephrology providers. Am J Kidney Dis 2017;69(3):451-60.

27. Ruela Ludmila de Oliveira, Siqueira Yeda Maria Antunes de, Gradim Clícia Valim Côrtes. Pain evaluation in patients under chemotherapy: application of McGill pain Questionnaire. Revista Dor 2017;18(2):156-60.

28. Barbosa IM, Sales DS, Oliveira LMS, Sampaio DV, Milhome AG. Pain in onco-hematologic patients and its association with analgesia. Rev Dor 2016;17(3):178-82.

29. Fillingim RB. Individual differences in pain: understanding the mosaic that makes pain personal. Pain 2017;15(Suppl1):11-8. 